\title{
THE SCOPE OF THE OBLIGATION TO RESPECT AND TO ENSURE RESPECT FOR INTERNATIONAL HUMANITARIAN LAW
}

\section{Tomasz Zych*}

This article disputes what seems to have become the dominant interpretation of the obligation to respect and to ensure respect for International Humanitarian Law, as codified in common Article 1 of the Geneva Conventions and in Article 1(1) of Additional Protocol I. According to this dominant interpretation, States are required to take all appropriate measures to ensure that IHL is observed universally, including by other States and by non-State actors operating in other States. It is argued that the intention of the High Contracting Parties, coupled with their subsequent practice, calls for a much more narrow interpretation of that obligation.

Cet article conteste ce qui semble être devenue l'interprétation dominante de l'obligation de respecter et de faire respecter le Droit International Humanitaire, tel que codifiée à l'article 1 commun aux Conventions de Genève et à l'article 1(1) du Protocole additionnel I. Selon cette interprétation dominante, les États doivent prendre toutes les mesures appropriées pour assurer que le DIH soit observé de façon universelle, y compris par d'autres États ainsi que par des acteurs non étatiques qui opèrent à l'intérieur d'autres États. On soutient que l'intention des Hautes Parties contractantes, en conjonction avec leur pratique subséquentes, laisse entendre une interprétation beaucoup plus étroite de cette obligation.

\section{INTRODUCTION}

It is a general principle of international humanitarian law [IHL] that States are obliged to respect and to ensure respect for IHL. ${ }^{1}$ This obligation is codified in both the Geneva Conventions ${ }^{2}$ and Additional Protocol $I,{ }^{3}$ and while it may seem

* Counsel, Public International Law Section, Department of Justice Canada. The opinions expressed in this article are those of the author and do not necessarily represent the views of the Department of Justice or of the Government of Canada.

1 Case concerning Military and Paramilitary Activities in and against Nicaragua (Nicaragua v. United States of America), [1986] I.C.J. Rep. 14, judgment of 27 June 1986 [Case concerning Military and Paramilitary Activities] at para. 220.

2 Geneva Convention (I) for the amelioration of the condition of the wounded and sick in Armed Forces in the field of August 12, 1949, 75 U.N.T.S. 31, Can. T.S. 1965 No. 20; Geneva Convention (II) for the amelioration of the condition of wounded, sick and shipwrecked members of Armed Forces at sea of August 12, 1949, 75 U.N.T.S. 85, Can. T.S. 1965 No. 20; Geneva Convention (III) relative to the treatment of prisoners of war of August 12, 1949, 75 U.N.T.S. 135, Can. T.S. 1965 No. 20; Geneva Convention (IV) relative to the protection of civilian persons in time of war of August 12, 1949, 75 U.N.T.S. 287, Can. T.S. 1965 No. 20 [Geneva Conventions].

3 Protocol Additional to the Geneva Conventions of 12 August 1949, and relating to the protection of 
non-contentious and indeed obvious, its precise scope remains controversial. According to one interpretation, which by force of repetition appears to have become dominant, States are required to ensure that IHL is respected not only by their own armed forces and within their respective jurisdictions, but universally by all around the world. Some writers have sought in this interpretation an overarching obligation that conveniently fills any gaps in existing rules of IHL. It has been argued, for instance, that the obligation to respect and to ensure respect for IHL requires States to regulate their arms exports so as to prevent violations of IHL by other actors. ${ }^{4}$ Similarly, the recently-concluded Swiss Initiative on Private Military and Security Companies [PMSCs], which had as its purpose to clarify the obligations of States in relation to PMSCs and to develop good practices, seemed to be premised on the existence of an obligation to ensure universal compliance with IHL on the part of private actors. ${ }^{5}$ This paper argues that this interpretation of the obligation to respect and to ensure respect for IHL is overly broad both as a matter of treaty law and custom. It argues that the intention of the States Parties to the Geneva Conventions and Additional Protocol I, coupled with their subsequent practice, calls for a much more narrow interpretation of that obligation.

\section{THE OBLIGATION TO RESPECT AND TO ENSURE RESPECT IN TREATY LAW}

In treaty law, the obligation to respect and to ensure respect for IHL is found in common Article 1 of the Geneva Conventions and in Article 1(1) of Additional Protocol I, which provide as follows:

The High Contracting Parties undertake to respect and to ensure respect for [the present Convention/this Protocol] in all circumstances. ${ }^{6}$

A similar provision was already found in both of the Geneva Conventions of 1929, although it required States Parties only to respect those Conventions:

Victims of International Armed Conflicts, 8 June 1977, 1125 U.N.T.S. 3, Can. T.S. 1991 No. 2 $[A P I]$.

4 Maya Brehm, "The Arms Trade and States' Duty to Ensure Respect for Humanitarian and Human Rights Law” (2008) 12 J. Confl. \& Sec. L. 359 at 359. See also Zeray Yihdego, The Arms Trade and International Law (Portland: Hart Publishing, 2007) at 199ff.

5 See e.g. the Brochure on the Montreux Document published by the sponsors of the Montreux initiative, which reads at page 33 that common Article 1 requires States to take all measures in their power to ensure respect for IHL on the part of PMSCS and that this obligation is "universal and applies to any State", online:

<http://www.eda.admin.ch/eda/en/home/topics/intla/humlaw/pse/psechi.html>. See also Hannah Tonkin, "Common Article I: A Minimum Yardstick for Regulating Private Military and Security Companies” (2009) 22 Leiden J. Int'l. L 779 (adopting the more nuanced view that the obligation to ensure respect for IHL by PMSCs applies only to States that actually have the "capacity to influence a particular PMSC effectively").

6 Geneva Conventions, supra note 2; API, supra note 3. 
The provisions of the present Convention shall be respected by the High Contracting Parties in all circumstances.

Surprisingly, the addition of the obligation to "ensure respect" did not arouse much interest or discussion at the Diplomatic Conference of 1949 nor indeed at the Diplomatic Conference of $1974-77 .{ }^{8}$ For a long time, scholars also tended to neglect this peculiar provision. ${ }^{9}$ More recently, however, the obligation to respect and to ensure respect for IHL has attracted more scholarly attention, notably as a possible overarching source of restraint on conduct not specifically regulated by existing rules of IHL.

The scholarship has focused mainly on the obligation to ensure respect for IHL, rather than on the more obvious obligation to respect it. Indeed, the latter obligation merely gives expression to the general principle of pacta sunt servanda, which was hardly in need of repeating even in 1929. As such, the scope of the obligation to respect IHL is quite clear and for the most part settled: it requires nothing more of States than to ensure that their own organs comply with IHL. ${ }^{10}$

In contrast to the obligation to respect, the obligation to ensure respect is not so easily defined. It has been the subject of two very different interpretations. ${ }^{11}$ According to one school of thought, which takes a broad view of the obligation to ensure respect, States are required to take all appropriate measures to ensure that IHL is observed universally, including by other States and by non-State actors operating in other States. ${ }^{12}$ The competing (narrow) view holds that the obliga-

7 Convention for the Amelioration of the Condition of the Wounded and Sick in Armies in the Field (27 July 1929), Article 25 and Geneva Convention Relative to the Treatment of Prisoners of War (27 July 1929), Article 83.

8 Frits Kalshoven, "The Undertaking to Respect and to Ensure Respect in all Circumstances: from Tiny Seed to Ripening Fruit" (1999) 2 Y.B. Int'l Human L. 3.

9 Nicolas Levrat, "Les conséquences de l'engagement pris par les Hautes Parties contractantes de "faire respecter " les Conventions humanitaires" in Frits Kalshoven \& Yves Sandoz, eds. Implementation of International Humanitarian Law (Dordrecht: Martinus Nijhoff Publishers, 1989) 263 at 263.

10 The ICRC and some like-minded academics take a broader view of the obligation to respect IHL, arguing that it includes also the obligation to ensure respect for IHL by "the population as a whole." See Claude Pilloud et al, eds., Commentary on the Additional Protocols of 8 June 1977 to the Geneva Conventions of 12 August 1949 (Geneva: Martinus Nijhoff, 1987) [Commentary on the Additional Protocols], under Article 1(1), API See also Laurence Boisson de Chazournes \& Luigi Condorelli, "Common Article 1 of the Geneva Conventions Revisited: Protecting collective interests” (2000) 837 Int'l Rev. Red Cross 67 [Common Article 1 Revisited]. However, exponents of this view provide no rationale for their contention and there appears to be no basis for it in either the negotiating history or in the texts themselves. As will be seen below, the Diplomatic Conference of 1949 referred to the duty to ensure respect for IHL by the population exclusively in connection with the obligation to "ensure respect." One can only speculate that the reason for referring to the population under the chapeau of the obligation to respect is to exclude it from the obligation to ensure respect so as to create the impression that the latter obligation must have been intended to apply more broadly.

11 "Improving Compliance with International Humanitarian Law: Proceedings of the Bruges Colloquium” 11-12 September 2003, Collegium no. 30 (Winter 2004) at 68.

12 The most notable exponents of this theory, other than the ICRC, are Luigi Condorelli and Laurence Boisson de Chazournes. See e.g. "Quelques remarques à propos de l'obligation des Etats 
tion to ensure respect applies only in respect of the State's own population and groups controlled by the State. On this view, there is no legal obligation to ensure respect for IHL by other States or by foreign non-State actors - only a moral obligation to do so. ${ }^{13}$

The broad view of the obligation to ensure respect for IHL was at one time based on the supposed intention of the High Contracting Parties to the 1949 Geneva Conventions and to Additional Protocol I. The International Committee of the Red Cross' [ICRC] Commentary on Additional Protocol I, for instance, maintained that the Diplomatic Conference of 1949 "fully understood and wished to impose [a] duty on each Party to the Conventions" to ensure universal compliance with IHL. ${ }^{14}$ This proposition was recently disproved, however, by Frits Kalshoven who pointed out that "there is nothing in the published records of the Conference that supports [the ICRC's] contention." 15 In fact, according to Kalshoven's thorough investigation of the negotiating history, "no-one at the Conference of 1949 or 1977 ever discussed the text of the Article in terms even remotely resembling the ICRC's interpretation, let alone ... qualified it as an obligation." ${ }^{16}$

Kalshoven disputes also the significance of Resolution XXIII adopted by the International Conference on Human Rights of 1969, which is often cited by

de " respecter et faire respecter " le droit international humanitaraire " en toute circonstance " in Christophe Swinarski, ed., Studies and essays on international humanitarian law and Red Cross principles (The Hague: Martinus Nijhoff, 1984) 17 at 24 [Quelques remarques]: "Sur chaque Etat pèse [...] l'obligation d'agir par tout moyen approprié afin que ces règles soient observées par tous, en particulier par les autres Etats." See also Paulo Benvenuti, "Ensuring Observance of International Humanitarian Law: Functions, Extent and Limits of the Obligation of Third States to Ensure Respect of International Humanitarian Law" (1989-90) Yearbook of the Institute of International Law.

13 Kalshoven, supra note 8 at 60. See also Hans-Peter Gasser, "Ensuring Respect for the Geneva Conventions and Protocols: The Role of Third States and the United Nations", in Hazel Fox \& Michael A. Meyer, eds., Armed Conflict and the New Law. Volume II: Effecting Compliance (London: British Institute of International and Comparative Law, 1993).

14 Commentary on the Additional Protocols, supra note 10, under Article 1.1, API.

15 Kalshoven, supra note 8 at 54. See also Adam Roberts, "The Laws of War: Problems of Implementation in Contemporary Conflicts" (1995-96) 6 Duke J. Comp. \& Int'l L. 11 at 2930:

This interpretation of Article 1 [the broad interpretation] does not appear to have a basis in the negotiating history of the 1949 Geneva Conventions. In the various meetings at Stockholm and Geneva, the words 'to ensure respect' had another meaning: To ensure that the whole population of a country which was party to the conventions would respect the law in all circumstances, even perhaps in the case of civil war. There appears to be little or nothing in the records of the 1949 Diplomatic Conference to suggest an awareness on the part of government delegates, or indeed ICRC participants, that the phrase 'to ensure respect' implied anything beyond internal observance.

See also Legal Consequences of the Construction of a Wall in the Occupied Palestinian Territory, Advisory Opinion, [2004] I.C.J. Rep. 136, separate opinion of Judge Higgins at para. 39: “The Final Record of the diplomatic conference of Geneva of 1949 offers no useful explanation of that provision [common Article 1]."

16 Kalshoven, supra note 8 at 52. 
proponents of the broad interpretation as one of their strongest arguments. Resolution XXIII appears to support their thesis by "noting" in preambular paragraph nine that:

States Parties to the Red Cross Geneva Conventions sometimes fail to appreciate their responsibility to take steps to ensure the respect of these humanitarian rules in all circumstances by other States, even if they are not themselves directly involved in an armed conflict.

Kalshoven points out, however, that Resolution XXIII was adopted without debate and argues that "the participants at the Conference may not all have been aware of the various possible interpretations of [common] Article 1."17 Kalshoven's view of Resolution XXIII is confirmed by the near-complete absence of such statements from international instruments adopted since 1969. Furthermore, it would seem that such other examples as do exist refer to serious violations of IHL and may therefore be interpreted as expressions not of a general obligation to ensure universal respect for IHL but of the obligation to address serious violations of IHL, ${ }^{18}$ as codified in Article 89 of Additional Protocol I for instance. ${ }^{19}$ It is also worth noting, that a recent attempt to insert similar language into a resolution of the Human Rights Council was rejected. ${ }^{20}$

Kalshoven concludes that, beyond the legal obligation of States to impose respect for IHL on their armed forces, their population and groups under their control, there is only a moral duty to endeavour to ensure universal respect for IHL. ${ }^{21}$

Proponents of the broad interpretation have taken little notice of Kalshoven's pointed critique. According to Eric David, the obligation to ensure universal respect for IHL cannot be of a merely moral order since the language of common Article 1 is prescriptive, not hortatory. ${ }^{22}$ This argument misses the point entirely. Kalshoven clearly recognises that common Article 1 expresses a legal obligation; what he disputes is the claim that this obligation is universal in scope. In other words, the dispute is not over the nature (legal or moral) of the obligation to ensure respect, but rather over the scope of the legal obligation. Kalshoven shows that common Article 1 of the Geneva Conventions and Article 1(1) of Additional

$17 \mathrm{Ibid}$. at p. 44. Indeed, the Participants appear not to have been aware that the Geneva Conventions of 1949 were not referred to as the "Red Cross Geneva Conventions."

18 See e.g. United Nations General Assembly, The uprising (intifadah) of the Palestinian people, GA Res. 21, UN GAOR, 43d session, Supp. No. 21, UN Doc. A/RES/43/21 (1988) (adopted by a vote of 130 in favour, two against, and 16 abstaining); See also Conference of High Contracting Parties to the Fourth Geneva Convention, Declaration, 5 December 2001.

19 See infra note 40 and accompanying text.

20 Human Rights Council, Protection of the human rights of civilians in armed conflict, UN. Doc. A/ HRC/9/L.21 (19 September 2008). An Egyptian draft of this resolution reproduced almost wordfor-word the text of preambular paragraph nine. The final text, however, merely "emphasized" that "States Parties to the Geneva Conventions of 1949 have undertaken to respect and ensure respect for these Conventions in all circumstances."

21 Kalshoven, supra note 8 at 60.

22 Eric David, Principes de droit des conflits armés, 3rd ed. (Brussels : Bruylant, 2002) at para. 3.14. 
Protocol I were never intended to create a legal obligation to ensure universal respect for IHL. The fact that he recognises the existence of a moral duty to do so (based on the "moral order" that underlies IHL) in no way detracts from his conclusion.

Other proponents of the broad interpretation dismiss Kalshoven's critique as a "minor consideration" and argue that the subsequent practice of States confirms their interpretation of the obligation to ensure respect. ${ }^{23}$ While they concede that very little evidence of State practice can actually be adduced in this regard, ${ }^{24}$ they speculate that this may be due to the preference of States to act discreetly, through diplomatic channels, rather than taking ostentatious measures to ensure compliance with IHL by others. Thus, they imply that there may in fact be sufficient State practice to establish the existence of a legally binding duty to ensure universal respect for IHL. ${ }^{25}$

This attempt at salvaging the broad interpretation appears to rest on Article 31(3)(b) of the 1969 Vienna Convention on the Law of Treaties, which provides that in interpreting a treaty account must be taken of "any subsequent practice in the application of the treaty which establishes the agreement of the parties regarding its interpretation." ${ }^{26}$ Article 31(3)(b) sets a very high standard; it requires that all parties to a treaty, if not actually engaged in the subsequent practice, must at least accept it or acquiesce to it. ${ }^{27}$ Any contrary State practice is therefore fatal to an argument based on Article 31(3)(b). In this case, such contrary State practice clearly exists. There are, for instance, domestic court decisions expressly rejecting the broad interpretation. ${ }^{28}$ There is also, as indicated above, evidence of

23 See e.g. Common Article 1 Revisited, supra note 10.

24 In fact, Luigi Condorelli and Laurence Boisson de Chazournes provide just one, rather unconvincing, example. See Quelques remarques, supra note 12, at 27. Cassese likewise concedes that since 1950 "few States took action [to ensure universal compliance with IHL], and always at the bilateral level: they sent diplomatic notes, or undertook diplomatic démarches, vis-à-vis belligerents grossly violating the Conventions. As these actions were never made public, one cannot gauge their importance and establish whether they had any follow-up." Antonio Cassese, International Law, $2^{\text {nd }}$ ed. (Oxford: OUP, 2004) at 20.

25 Ibid.

26 Vienna Convention on the Law of Treaties, 23 May 1969, 1155 U.N.T.S. 331, Can. T.S. 1980 No. 37.

27 See International Law Commission, Draft Articles on the Law of Treaties with commentaries, Yearbook of the International Law Commission, 1966, vol. II, at 222. See also Anthony Aust, Modern Treaty Law and Practice, $2^{\text {nd }}$ ed. (Cambridge, Cambridge University Press, 2007) at 241.

28 The best example is Sinnappu v. Canada (Minister of Citizenship and Immigration), [1997] 2 F.C. 791 at para. 81 (T.D.) (holding that "[s]ince Canada has no involvement whatsoever in that dispute [the internal armed conflict in Sri Lanka] common Article 1 of the Geneva Conventions, 1949 does not impose upon our country an obligation to ensure that the parties to that conflict respect common Article 3." Appeal dismissed for mootness, [1999] F.C.J. No. 2023. See also American Baptist Churches v. Meese, 712 F.Supp. 756 (N.D. Cal. 1989) (holding that " $\mathrm{t}]$ he language used [in common Article 1] does not impose any specific obligations on the signatory nations, nor does it provide any intelligible guidelines for judicial enforcement"). There is, however, at least one judgment that supports the broad interpretation: Hamdan v. Rumsfeld, 367 U.S. App. D.C. 265 (2005) (holding that the undertaking "to ensure respect" for the Conventions "imposed upon signatory nations the duty not only of complying themselves but also of making sure other signatories complied"). Reversed and remanded on other grounds, 126 S. Ct. 2749 (2006). 
State opposition to resolutions affirming the broad interpretation. ${ }^{29}$

Even in the absence of this contrary State practice, however, it would be difficult to argue that States had acquiesced to the broad interpretation. Acquiescence, as Ian Brownlie succinctly puts it, is "the absence of protest when this might reasonably be expected." ${ }^{30} \mathrm{Or}$, to use I.C. MacGibbon's definition, acquiescence consists of "silence or absence of protest in circumstances which generally call for a positive reaction signifying an objection." ${ }^{31}$ Those circumstances include above all a certain notoriety of practice. ${ }^{32}$ A practice that is engaged in discreetly or secretly on a bilateral level, as is alleged to be the case here, would not be known to the generality of States and would not afford them an opportunity to protest. The silence of States in such circumstances could not be interpreted as tacit agreement with the broad interpretation. Furthermore, even if such practice existed and came to the knowledge of some States, their silence might reasonably result from mere indifference. As will be seen below, there is no reason to believe that a meaningful number of States subscribes to the broad interpretation. In such circumstances, it would be entirely reasonable for the great majority of States not to feel compelled to dispute the minority's understanding of the law.

Antionio Cassese seems to be aware of this weakness and relies instead on Article 32 of the Vienna Convention, which allows recourse to "supplementary means of interpretation." 33 This variant, however, is no more persuasive than the first. While subsequent practice which does not meet the requirements of Article 31(3)(b) may nevertheless be taken into consideration as a supplementary means of interpretation, ${ }^{34}$ Article 32 should not be used to circumvent Article $31(3)$ (b). If subsequent practice is insufficient to produce a certain result under Article 31(3)(b) because of the existence of contrary State practice (as in this case), then it must also be insufficient to produce that result under Article 32. To argue otherwise would be to accept that a treaty may be modified through subsequent practice over the objection of one or more State parties. Such use of subsequent practice would be completely at odds with the basic principle of consent. Mention should also be made of the interpretative principle of in dubio mitius, which like Article 32 applies in cases of ambiguity. It provides that "[i]f the meaning of a term is ambiguous, that meaning is to be preferred which is less onerous to the party assuming an obligation, or which interferes less with the territorial and personal supremacy of a party, or involves less general restrictions upon the parties." ${ }^{35}$ This principle is particularly apposite in this case given

29 See supra notes 18 and 20 and corresponding text.

30 Ian Brownlie, Principles of Public International Law, $7^{\text {th }}$ ed. (Oxford: Oxford University Press, 2008) at 152.

31 I.C. MacGibbon, The Scope of Acquiescence in International Law (1954) 31 Brit. Y. B. Int'l L. 143 at 143 .

32 V.D. Degan, Sources of International Law (The Hague: Kluwer Law International, 1997) at 353.

33 Cassese, supra note 24 at 18 , n. 6.

34 See e.g. Yves Le Bouthillier, "Article 32 - Convention de 1969”, in Olivier Corten \& Pierre Klein, eds., Les Conventions de Vienne sur le droit des traités: Commentaire article par article (Brussels: Bruylant, 2006), 1339 at 1366 . See also Brownlie, supra note 30 at 6.

35 Sir Robert Jennings \& Sir Arthur Watts, eds., Oppenheim's International Law, $9^{\text {th }}$ ed. (London: Longman, 1996) vol. 1 at 1278. 
the stark practical implication of requiring States to ensure universal respect for IHL. An even more fundamental flaw in the "subsequent practice" argument is the assumption that the necessary State practice actually exists. It is trite law that one may not rely on such assumptions even if the practice in question is alleged to be secret. Whether for the purposes of treaty law or custom, the existence of State practice must always be established. Moreover, it is not clear why evidence of State practice in this area should be particularly difficult to find in the first place. Indeed, if the obligation to ensure respect for IHL were in fact universal in scope and "universally accepted" as such by States, as claims Cassese, ${ }^{36}$ each and every armed conflict (or at least each and every armed conflict that involved violations of IHL) would elicit some kind of response by each and every State. Even if the response in question were nothing more than a discreet diplomatic démarche (which is the least that each and every State would presumably be required to do), the resulting practice would be too abundant to miss. Given the sheer volume of the practice, at least some of it would eventually and inevitably find its way into the public domain. ${ }^{37}$ There is, for instance, abundant evidence of espionage $e^{38}-$ an eminently secret activity. In any event, it is a mistake to assume that all States would in all cases prefer to pursue quiet diplomacy; it stands to reason that in some cases States would find it in their interest publicly to invoke their duty to ensure universal respect for IHL (if they thought that such a duty existed) as a pretext for censuring or taking coercive measures against other States or foreign non-State actors. States may also consider public statements to be more effective than quiet diplomacy in certain circumstances or may want publicly to demonstrate their support for IHL. ${ }^{39}$ Accordingly, the admitted paucity of State practice cannot be explained on the basis of the secretive nature of diplomacy. A much more likely explanation is that States simply do not subscribe to the broad interpretation.

It bears mention also that proponents of the broad interpretation are not helped by the several instances in which the United Nations [UN] has called upon parties to a conflict to respect IHL and in which UN member States have contributed troops to peacekeeping missions or UN-authorised interventions. Such practice is more consistent with the obligation of States, pursuant to Article

36 Cassese, supra note 24, at 18, n. 6. See also Marco Sassòli, "State responsibility for violations of international law” (2002) 84 Int'l Rev. Red Cross at 421. According to Sassòli, the obligation to "ensure respect" in common Article 1 "is today unanimously understood as referring to violations by other States."

37 In Canada, for instance, Cabinet confidences cease to be treated as such for the purposes of disclosure after 20 years. See Access to Information Act, R.S.C. 1985, c. A-1, s. 69(3)(a). See also Canada Evidence Act, R.S.C. 1985, c. C-5, s. 39(4)(a).

38 See e.g. Roger D. Scott, "Territorially Intrusive Intelligence Collection and International Law" (1999) 46 A.F.L. Rev. 217, n 15 and accompanying text.

39 Switzerland, for instance, twice in 2009 issued public appeals to the parties to the conflict in Sri Lanka to respect and to ensure respect for IHL. Swiss Federal Department of Foreign Affairs, Press release, "The FDFA appeals to all the conflicting parties in Sri Lanka to respect humanitarian law" (5 February 2009), "The FDFA appeals to all the conflicting parties in Sri Lanka to end the hostilities immediately and to respect international humanitarian law” (21 April 2009). Neither statement makes clear whether Switzerland issued the appeals out of a sense of legal obligation to ensure universal respect for IHL. 
89 of Additional Protocol I, to address serious violations of IHL in cooperation with the UN, rather than with the broad interpretation of common Article $1 .^{40}$ Article 89 provides as follows:

In situations of serious violations of the Conventions or of this Protocol, the High Contracting Parties undertake to act, jointly or individually, in co-operation with the United $\mathrm{Na}$ tions and in conformity with the United Nations Charter.

Unlike common Article 1, Article 89 clearly refers to violations of IHL committed by other parties to an armed conflict. Article 89 , however, applies only in "situations of serious violations" and requires the High Contracting Parties to act in cooperation with the UN and in conformity with the UN Charter. In that sense, Article 89 is not unlike Article 4(h) of the Constitutive Act of the African Union, which provides for the "right of the Union to intervene in a Member State pursuant to a decision of the Assembly in respect of grave circumstances, namely war crimes, genocide and crimes against humanity." Article 89 expresses essentially the same idea as Article 41(1) of the International Law Commission's Draft Articles on State Responsibility ${ }^{41}$ which provides that States shall cooperate to put an end to serious breaches of jus cogens through lawful means. Reference may also be made to the 2005 World Summit Outcome document in which participating States declared their preparedness to:

[T]ake collective action, in a timely and decisive manner, through the Security Council, in accordance with the Charter, including Chapter VII, on a case-by-case basis and in cooperation with relevant regional organizations as appropriate, should peaceful means be inadequate and national authorities are manifestly failing to protect their populations from genocide, war crimes, ethnic cleansing and crimes against humanity. ${ }^{42}$

It is no coincidence that all of these provisions apply only in respect of serious violations of international law and that they authorize only collectively-sanctioned actions. The absence of similar language from common Article 1 is further proof that the High Contracting Parties never intended to create a broader obligation to ensure universal respect for IHL. It also bears mention that while Article 89 refers to serious violations of IHL that have already occurred or are occurring, the broad interpretation of common Article 1 would require States to take such measures as they can to prevent violations.

40 API, supra note 3.

41 International Law Commission, Draft Articles on Responsibility of Stats for Internationally Wrongful Acts, with commentaries, Yearbook of the International Law Commission, 2001, vol. II, Part Two [Draft Articles on State Responsibility].

42 UN GA, 2005 World Summit Outcome, GA Res. 60/1, 60 ${ }^{\text {th }}$ Sess., UN Doc. A/RES/60/1 (2005) at para. 139 . 


\section{THE OBLIGATION TO RESPECT AND TO ENSURE RESPECT UNDER CUSTOMARY INTERNATIONAL LAW}

In view of the general recognition (even on the part of broad interpretation proponents) that evidence of State practice is lacking, it is surprising to find that the authors of the recent ICRC Study on Customary International Humanitarian $L a w^{43}$ present the broad interpretation as an established rule of customary IHL and claim that evidence in support of it is "overwhelming." The broad interpretation is summed up in the second sentence of Rule 144 of the Study, which reads as follows:

States may not encourage violations of international humanitarian law by parties to an armed conflict. They must exert their influence, to the degree possible, to stop violations of international humanitarian law.

The commentary to rule 144 begins with a discussion of common Article 1. It reiterates the ICRC's long-standing position that common Article 1 is a source of obligation for all High Contracting Parties (not just those involved in an armed conflict) and "includes the requirement that States do all in their power to ensure that international humanitarian law is respected universally." ${ }^{44}$ The commentary goes on to assert that "State practice shows an overwhelming use of (i) diplomatic protest and (ii) collective measures through which States exert their influence, to the degree possible, to try to stop violations of [IHL].”45

Unfortunately, the ICRC has made it very difficult to verify this claim. As the commentary explains, evidence of State practice in support of rule 144 is catalogued throughout the Study "in the context of the various rules covered by [it]" - presumably because the practice was too "overwhelming" to catalogue in one place. The decision to proceed in this way is puzzling given that the ICRC must have been aware that scholars had so far failed to produce convincing evidence of State practice in this regard and that the matter was contentious. In fact, even ICRC officials had in the past admitted that such evidence was insufficient or at least inconclusive. Hans-Peter Gasser, writing in his personal capacity, stated not so long ago that it was "difficult to draw conclusions from the practice of governments" and that no "clear" or "hard" evidence of State practice had emerged in this area. ${ }^{46}$ He concluded that:

[A] brief look at the behaviour of governments leaves no doubt that they do not feel themselves to be under a legal obligation to act if humanitarian law is being flouted by a

43 Jean-Marie Henckaerts \& Louise Doswald-Beck, Customary International Humanitarian Law, vol. 1 (Cambridge: Cambridge University Press, 2005) [ICRC Study].

44 Ibid. at $509-10$.

45 Ibid. at 512.

46 Gasser, supra note 13 at 31. 
party to an armed conflict. If third parties actually do act, they do so if and when they feel that a démarche is also in their own interest or if public pressure at home is such that to act seems wiser than to run counter to public opinion. ${ }^{47}$

Cornelio Sommaruga expressed a similar view while serving as President of the ICRC. He opined that States had only a moral obligation to act if other States violated IHL, which in his view was "even more important" than having a legal obligation to do so. ${ }^{48}$

These comments bring us to the issue of opinio juris, of which there is scarcely any mention in the commentary to rule 144 . In considering this issue it is important to keep in mind that rule 144 comprises two sentences each of which articulates a separate norm. The first sentence of rule 144 sets out a prohibition against encouraging violations of IHL by parties to an armed conflict, while the second sentence refers to a positive obligation of States to exert their influence to the degree possible to stop such violations. This distinction is important because, as stated in the introduction to the Study, the manner of assessing the existence of a customary rule "may well differ depending on whether the rule involved contains a prohibition, an obligation or merely a right to behave in a certain manner." ${ }^{39}$ In the case of a right, it may be sufficient to show that States do not object when others act in a certain way. ${ }^{50}$ Prohibitions, on the other hand, require positive evidence of opinio juris, particularly where the underlying State practice consists primarily of abstentions (i.e. compliance with the prohibition). Such evidence might consist of protests against violations of a prohibition or of declarations by States to the effect that certain conduct is prohibited. Positive evidence of opinio juris is arguably even more important in the context of obligations in order to distinguish the underlying State practice from mere courtesy or comity. As the authors of the Study observe:

The fact that it is a legal requirement, rather than one reflecting courtesy or comity, can be found by either an expression of the need for such behaviour, or by criticism by other States in the absence of such behaviour. It may also be that, following criticism by other States, the criticised State will explain its abstinence by seeking justification within the rule. ${ }^{51}$

Furthermore, as noted in the Study, "[o]pinio juris plays an [especially] important role ... where the practice is ambiguous, in order to decide whether or not that practice counts towards the formation of custom." 52

The commentary to rule 144 shows no indication of these basic rules having

47 Ibid. at 32.

48 Kalshoven, supra note 8 at 60.

49 ICRC Study, supra note 43 at xxxix.

$50 \mathrm{Ibid}$. at xl.

51 Ibid.

52 Ibid. 
been followed. The methodology actually employed with regards to rule 144 is more appropriate for establishing the existence of a customary right, rather than a prohibition or obligation. The authors of the Study appear to have admitted any State practice whether or not supported by evidence of opinio juris. With respect to diplomatic protests, for instance, the commentary notes that " $[\mathrm{s}] \mathrm{uch}$ protests have, on occasion, referred specifically to the duty of States, under common Article 1 of the Geneva Conventions, to ensure respect for international humanitarian law." 33 What the authors mean, presumably, is that in some cases the protesting State had invoked its own obligation under common Article 1 as the reason for its protest. Such references to common Article 1 would indeed constitute evidence of opinio juris in support of an obligation to ensure universal respect for IHL. Not a single example of such a protest is provided, however. Furthermore, the authors do not explain whether the remaining protests disclosed any similar evidence of opinio juris. There is no consideration of the possibility that these protests may have been motivated by extra-legal considerations.

Another difficulty which appears to have been overlooked by the authors of the Study is that declarations consistent with the existence of a norm are often contradicted by the actual practice of the very States making those declarations. Recent attempts by Switzerland to regulate private military and security companies [PMSCs] offer an interesting case in point. In 2005, the Swiss Federal Council published a report on PMSCs in which it explicitly recognized the existence of an obligation, based on common Article 1, to ensure universal respect for IHL. ${ }^{54}$ According to the report, States "have to ensure ... that the private security companies which they deploy in conflict situations, which are based in their state or which are operational on their territory, respect international humanitarian law." ${ }^{5}$ The Council seemed to reverse itself, however, in May 2008 when it decided to not regulate Swiss exports of private military and security services. ${ }^{56}$ Among the reasons cited for this decision were the "minor importance" of the Swiss PMSC industry and the difficulty of enforcing legislation extraterritorially. The Council noted also that "with the exception of the USA and South Africa, no major provider state governs the export of military and security services beyond its existing legislation on arms." The Council made no reference, however, to IHL and did not attempt to reconcile its decision to not regulate with its earlier finding that it was obliged to do so. Interestingly, the Council referred to the size of the Swiss PMSC industry only in connection with

53 Ibid. at 512. Emphasis added.

54 Report by the Swiss Federal Council on Private Security and Military Companies (2 December 2005), at para. 5.3.3 [Report by the Swiss Federal Council]: "Common Article 1 of the four Geneva Conventions states that the States Parties undertake to respect and to ensure respect for the present convention under all circumstances. This means that the States Parties must see to it that all state players respect international humanitarian law. Moreover the contracting states have the duty to ensure that third parties, whether they are other states or private entities, also observe international humanitarian law."

55 Ibid.

56 Federal Department of Justice and Police, Press Release, "Private security companies operating in conflict regions will not be registered" (21 May 2008). 
"the risk of incidents that might have a detrimental effect on the foreign and security policy or the neutrality" of Switzerland ${ }^{57}-$ it did not cite it as a factor justifying non-regulation at international law.

The Swiss Federal Council's characterisation of the industry's importance as "minor" is in itself interesting. According to a report by the Geneva Centre for the Democratic Control of Armed Forces [DCAF], which had been commissioned by the Swiss government to study the Swiss PMSC industry and explore regulatory options, there were in 2007 no fewer than 23 Swiss firms "that have worked, or seek to work, beyond Western Europe and North America." 58 The expression "beyond Western Europe and North America" was a euphemism coined by the DCAF to accommodate PMSCs that might have been reluctant to admit that they had, or were seeking, contracts in conflict zones. ${ }^{59}$ Even so, of the 23 firms identified by the DCAF, only twelve agreed to participate in the study, making any conclusions about the industry as a whole necessarily tentative. The Swiss government, however, appears not to have been overly concerned with the resulting uncertainty about the nature and extent of activities undertaken by Swiss PMSCs. A report by the Federal Office of Justice concluded simply that the refusal of some firms to participate in the DCAF study did not warrant the inference that they were active in conflict zones or had anything to hide from the authorities. ${ }^{60}$

This approach was in stark contrast to the concern voiced by the Council in its 2005 report. There, the Council noted that just in the canton of Basel-Landschaft (by no means the largest or most populous of Switzerland's 26 cantons) there were three firms "known to be operating in war zones or crisis areas" and twelve more which had informed the authorities that they were considering such work. ${ }^{61}$ The Council found that while there still were "not many Swiss-based private security companies operating in crisis zones abroad" there were indications that "such activities [were] likely to grow in importance." ${ }^{2}$ Viewing the Council's decision to not regulate in light of its 2005 Report, one is left with the distinct impression that Swiss authorities had, by 2007, somehow lost all desire to regulate PMSCs and did not want to be persuaded otherwise by looking too deeply into their activities. The decision to not regulate PMSCs appears to have been dictated by policy considerations and to have had little, if anything, to do with international law.

The methodological shortcomings outlined above are not unique to rule 144. The methodology employed by the authors of the Study has been widely

57 See also the Report of the Federal Office of Justice on which the Council's decision was based (not available in English): Rapport de l'Office fédéral de la justice sur l'examen d'un système d'enregistrement obligatoire des entreprises de sécurité actives dans les zones de crise ou de conflit [Rapport de l'Office fédéral de la justice].

58 See Geneva Centre for the Democratic Control of Armed Forces, Report on Swiss-Based Military and Security Service Providers Operating in Crisis and Conflict Regions, Phase I: The Swiss Market (5 November 2007) at 6.

59 Ibid. at 4.

60 Rapport de l'Office fédéral de la justice, supra note 57 at para. 2.1.1.

61 Report by the Swiss Federal Council, supra note 54 at 19.

62 Ibid. 
criticised. ${ }^{63}$ Iain Scobbie, for instance, has observed that there appears to be a divergence between the "classic" approach to assessing the existence of customary international law as described in the introduction to the Study and "the less stringent methodology which actually appears to have been employed" in the context of particular rules. ${ }^{64}$ Scobbie's observation certainly applies in this case.

Another criticism levelled against rule 144 is that the expression "to the degree possible" makes it "too uncertain to be admitted as a norm of customary international law." 65 This concern appears to be exaggerated, however, given the decision of the International Court of Justice [ICJ] in the Case concerning the Application of the Genocide Convention. ${ }^{66}$ There, the Court interpreted the undertaking to prevent genocide ${ }^{67}$ as requiring States "to employ all means reasonably available to them, so as to prevent genocide so far as possible" and recognised that this obligation "varies greatly from one State to another" depending on "the capacity [of each State] to influence effectively the action of persons likely to commit, or already committing, genocide." ${ }^{68}$ Notwithstanding the inherent difficultly of applying such a vague norm, the Court was able to conclude that the Federal Republic of Serbia had breached its obligation to prevent genocide by failing to take any steps to prevent the Srebrenica massacre. ${ }^{69}$ In light of this judgment, it would seem that the second sentence of rule 144 (requiring States to "exert their influence, to the degree possible, to stop violations of international humanitarian law") is not so unclear and imprecise as to be invalid as a legal norm.

It remains, however, that the second sentence of rule 144 is terribly vague, which makes it unlikely for States to be found in violation of it so long as they at least refrain from encouraging violations of IHL. It is interesting to note in

63 See generally Elizabeth Wilmshurst \& Susan Breau, eds., Perspectives on the ICRC Study on Customary International Humanitarian Law (Cambridge: Cambridge University Press, 2007) [Perspectives on the ICRC Study]; David Turns, "Weapons in the ICRC Study on Customary International Humanitarian Law” (2006) 11 J. Confl. \& Sec. L. 201; John B. Bellinger III \& William J. Hayes II, "A US Government Response to the International Committee of the Red Cross Study on Customary International Humanitarian Law” (2007) 89 Int'l Rev. Red Cross 443-71.

64 Iain Scobbie, "The Approach to Customary International Law" in Perspectives on the ICRC Study, ibid., 15 at 25.

65 David Turns, "Implementation and Compliance" in Perspectives on the ICRC Study, ibid. 354 at 367. See also American Baptist Churches v. Meese, 712 F.Supp. 756 (N.D. Cal. 1989) (holding that " $\mathrm{t}$ ]he language used [in common Article 1] does not impose any specific obligations on the signatory nations, nor does it provide any intelligible guidelines for judicial enforcement").

66 Case concerning the Application of the Convention on the Prevention and Punishment of the Crime of Genocide (Bosnia and Herzegovina v. Serbia and Montenegro), Judgment of 26 February 2007, General List No. 91 [Case concerning the Application of the Genocide Convention].

67 Article 1 of the Convention on the Prevention and Punishment of the Crime of Genocide provides as follows: "The Contracting Parties confirm that genocide, whether committed in time of peace or in time of war, is a crime under international law which they undertake to prevent and to punish." At para. 429 of its judgment, the Court notes that this provision is not unique and provides a list (admittedly non-exhaustive) of similar provisions, which does not include common Article 1. Convention on the Prevention and Punishment of the Crime of Genocide, 9 December 1948, 78 U.N.T.S. 277, Can. T.S. 1949 No. 27 [Genocide Convention].

68 Case concerning the Application of the Genocide Convention, supra note 66 at para. 430.

69 Ibid. at para. 438. 
this regard that rule 144 juxtaposes two seemingly distinct ideas: the prohibition against encouraging violations of IHL (first sentence) and the obligation to "exert their influence, to the degree possible, to stop" such violations (second sentence). This juxtaposition is a telling indication of the true scope of the obligation to ensure respect for IHL universally. In fact, the only sure way to violate the second sentence of rule 144 might be to violate the first. As Marco Sassòli and Antoine Bouvier have noted, "it is only certain that a State violates [common] Article $1 \ldots$ if it encourages or assists violations by another State." ${ }^{70}$ This view is consistent with international jurisprudence, which so far has not extended the duty to ensure universal respect for IHL beyond the duty not to encourage violations of IHL by others.

In the Case concerning Military and Paramilitary Activities in and against Nicaragua ${ }^{71}$ which no doubt inspired rule 144, the ICJ held that the United States had, by virtue of the duty to ensure respect for IHL, an obligation not to encourage violations of IHL by the contras:

[T] here is an obligation on the United States Government, in the terms of Article 1 of the Geneva Conventions, to "respect" the Conventions and even "to ensure respect" for them "in all circumstances", since such an obligation does not derive only from the Conventions themselves, but from the general principles of humanitarian law to which the Conventions merely give specific expression. The United States is thus under an obligation not to encourage persons or groups engaged in the conflict in Nicaragua to act in violation of the provisions of Article 3 common to the four 1949 Geneva Conventions. ${ }^{72}$

Given how this passage has been interpreted by the authors of the Study, it may be useful to put it in perspective. It will be recalled that the United States was involved in the conflict in Nicaragua both directly (by laying mines in Nicaraguan ports, for instance) and indirectly by training, arming, financing and supplying the contra forces. By virtue of its support for the contras, the United States exercised a degree of influence over them that would have allowed it to do much more than merely refrain from encouraging violations of IHL. Indeed, as the Court noted, "a degree of control by the United States Government [was] inherent in the position [of dependence] in which the contra force [found] itself in relation to that Government."73 Furthermore, the Court found that United States authorities "were aware of, at the least, allegations that the behaviour of the contras in the field was not consistent with humanitarian law." ${ }^{74}$ Despite this influence and knowledge, there is nothing in the judgment to suggest that the

70 Marco Sassòli \& Antoine Bouvier, How Does Law Protect in War? (Geneva: ICRC, 1999) at 231.

71 Case concerning Military and Paramilitary Activities, supra note 1.

72 Ibid. at para. 220.

73 Ibid. at para. 111.

74 Ibid. at para. 256. 
United States was required to take any positive steps to stop violations of IHL by the contras. The Court did not suggest that the United States should have made use of its influence in order to ensure or promote respect for IHL by the contras. The United States' only obligation, in view of the Court, was not to encourage such violations. Interestingly, the Court found that the United States had breached this obligation in only one respect, namely, by supplying the contras with a manual on psychological warfare, which explicitly advocated conduct that is prohibited under IHL.

The Court reached a similar conclusion in its Advisory Opinion on the Legal Consequences of the Construction of a Wall in the Occupied Palestinian Territory. There, the Court held that Israel's violations of erga omnes obligations created certain obligations for all States. The Court again framed these obligations in negative terms, stating that "[a]ll States are under an obligation not to recognize the illegal situation resulting from the construction of the wall and not to render aid or assistance in maintaining the situation created by such construction." 75 The Court held that in addition to these obligations, all States Parties to the Fourth Geneva Convention had also "the duty to ensure compliance by Israel with international humanitarian law as embodied in that Convention." ${ }^{\prime 6}$ Interestingly, the Court did not specify what (if anything) this duty entailed beyond the negative obligations not to recognize and not to assist. There is no indication that the Court had in mind positive obligations. On the contrary, given the specific mention of negative obligations in the very same paragraph, it is fair to assume that the Court would have mentioned any positive obligations if it were of the view that such obligations existed. Indeed, proponents of the broad interpretation have criticised this aspect of the Court's decision and have been at pains to explain it. ${ }^{77}$

This interpretation of the Court's Advisory Opinion is consistent with the submissions of States participating in the case. Of the eight interveners that addressed the issue, only the League of Arab States ${ }^{78}$ (acting apparently in its own capacity and not on behalf of its member States) and Egypt ${ }^{79}$ suggested that third parties had a positive duty, based on common Article 1, to ensure respect for the Third Geneva Convention by Israel. Palestine, the party with the greatest interest in advancing the law on this point, also referred to common Article 1 but did not interpret it as requiring third parties to take any positive steps to

75 Legal Consequences of the Construction of a Wall in the Occupied Palestinian Territory, Advisory Opinion, [2004] I.C.J. Rep. 136, at para. 159 and para. D of the dispositif. Cf. separate opinion of Judge Higgins at para. 39 (arguing that "the erga omnes' nature of violations of humanitarian law seems... irrelevant" and that common Article 1 "is simply a provision in an almost universally ratified multilateral Convention").

76 Ibid.

77 See e.g. Iain Scobbie, "Smoke, Mirrors and Killer Whales: the International Court's Opinion on the Israeli Barrier Wall” (2004) 5 German Law Journal 1107 at 1125. See also Ardi Imseis, "Critical Reflections on the International Humanitarian Law Aspects of the ICJ Wall Advisory Opinion” (2005) 99 A.J.I.L. 102 at 115.

78 Written Statement of the League of Arab States, at para. 11.8. See also the oral pleadings of the League of Arab States, Verbatim Record 2004/5 at 32. All written and oral pleadings available online at < http://www.icjcij.org/docket/index.php?p1=3\&p2=4\&code=mwp\&case=131\&k=5a> .

79 Legal Memorandum submitted by the Arab Republic of Egypt, at 35. 
ensure respect for the Convention. ${ }^{80}$ While Palestine argued that third States had an "obligation to cooperate with each other and with the responsible international bodies, with a view to putting an end to Israel's violations," it based this obligation on Draft Article 40 on the Responsibility of States, which, as mentioned above, deals only with situations of serious violations of jus cogens. ${ }^{81}$ Saudi Arabia suggested that the obligations of third parties were limited to enacting penal sanctions for persons committing grave breaches of the Convention and to prosecuting such persons. ${ }^{82}$ Jordan and Indonesia, relying apparently on Article 2 of the UN Charter, argued that third States had certain obligations as Members of the United Nations, including the obligation to recognise the illegality of the situation and to take lawful measures to bring it to an end. ${ }^{83}$ Sweden referred to Draft Article 16 on the Responsibility of States and stated that "third states must not aid or assist Israel in its measures." ${ }^{84}$ Finally, Pakistan stated, without elaborating, that " $[\mathrm{t}]$ he international community has an obligation to prevent unlawful annexation of Palestinian land." 85 These submissions show that proponents of the broad interpretation were in the minority. Furthermore, the variety of views expressed may explain why the Court did not venture to create new law by recognising the existence of a customary rule requiring States to ensure universal respect for IHL. Accordingly, it appears that the Court's Advisory Opinion is entirely consistent with its earlier decision in the Case concerning Military and Paramilitary Activities.

These decisions may be contrasted with the more recent judgment of the Court in the Case concerning the Application of the Genocide Convention. ${ }^{86}$ Of interest for our purposes is the part of the Judgment that deals with the obligation to prevent genocide. This obligation is codified in Article 1 of the Convention on the Prevention and Punishment of the Crime of Genocide, ${ }^{87}$ which provides as follows:

The Contracting Parties confirm that genocide, whether committed in time of peace or in time of war, is a crime under international law which they undertake to prevent and to punish.

The Court reiterated that the obligation to prevent genocide "is not territorially limited by the Convention." 88 It further stated that the obligation to prevent

80 Written Statement Submitted by Palestine, at 291ff. Palestine argued that third parties had an obligation to cooperate to bring the situation to an end, but did soon the basis of Draft Article 40 on State Responsibility, which is concerned with grave breaches.

$81 \mathrm{Ibid}$. at para. 635-36.

82 Written Statement of the Kingdom of Saudi Arabia, at 22-23.

83 Written Statement Submitted by the Hashemite Kingdom of Jordan, at 150-51; Written Statement Submitted by the Government of the Republic of Indonesia, at para. 9.

84 Written Statement of the Swiss Confederation, at para. 10.

85 Written Statement submitted by the Islamic Republic of Pakistan, at para. X.

86 Case concerning the Application of the Genocide Convention, supra note 66.

87 Genocide Convention, supra note 67.

88 Case concerning the Application of the Genocide Convention, supra note 66 at para. 153. 
genocide is one of conduct and requires States Parties to the Convention "inter alia, to employ the means at their disposal ...to prevent persons or groups not directly under their authority from committing an act of genocide." ${ }^{99}$ This duty, according to the Court, requires a State to act the instant it "learns of, or should normally have learned of, the existence of a serious risk that genocide will be committed." ${ }^{90}$ In applying the law to the facts, the Court found that the Federal Republic of Yugoslavia (FRY) met both of the requirements of Article 1. First, it enjoyed a position of influence over the persons who perpetrated the genocide in Srebrenica "owing to the strength of the political, military and financial links between the FRY on the one hand and the Republika Srpska and the VRS [Army of the Republika Srpska] on the other." ${ }^{11}$ Second, the Court concluded that the authorities of the FRY "could hardly have been unaware of the serious risk of [genocide] once the VRS forces had decided to occupy the Srebrenica enclave." 92 Accordingly, the Court concluded that the authorities of the FRY should have "made the best efforts within their power to try and prevent the tragic events then taking shape." 93

The Case concerning the Application of the Genocide Convention demonstrates that the Court can be quite liberal and progressive in its interpretation of treaty provisions of a humanitarian character and that it is not on principle opposed to recognising an obligation to make best efforts (similar to the second sentence of rule 144), despite the inherent vagueness of such an obligation, if it considers it to have a rational basis in the text of the treaty. ${ }^{94}$ Far from assisting proponents of the broad interpretation, this aspect of the decision suggests that the Court had good reason not to interpret common Article 1 of the Geneva Conventions in a similarly expansive fashion in the Case concerning Military and Paramilitary Activities and in its Advisory Opinion on the Wall. In particular, it will be recalled that the relationship between the United States and the contras in the Case concerning Military and Paramilitary Activities was not unlike the relationship between the FRY and the VRS in the Case concerning the Application of the Genocide Convention.

It follows from this analysis that the second sentence of rule 144 is not a correct statement of the law. As already demonstrated, the proposition that States "must exert their influence, to the degree possible, to stop violations of international humanitarian law" does not reflect the intention of the High Contracting Parties and is not supported by subsequent State practice or case law.

$89 \mathrm{Ibid}$. at para. 166. See also para. 430.

90 Ibid. at para. 431.

91 Ibid. at para. 434.

92 Ibid. at para. 436.

93 Ibid. at para. 438.

94 The Court's apparent tolerance for vagueness in the Genocide case (in the context of a treaty obligation) may be contrasted with its strict approach towards unilateral declarations. In the Case concerning Armed Activities on the Territory of the Congo, the Court held that a unilateral declaration "can create legal obligations only if it is made in clear and specific terms." Case concerning Armed Activities on the Territory of the Congo (New Application: 2002) (Democratic Republic of the Congo v. Rwanda), Judgment of 3 February 2006, General List No. 126, at para. 50. 


\section{THE ACTUAL SCOPE OF THE OBLIGATION TO RESPECT AND TO ENSURE RESPECT FOR IHL}

Having concluded that the broad interpretation of common Article 1 is incorrect and that there is no customary obligation to exert influence, to the degree possible, to stop violations of IHL, it falls now to consider what common Article 1 actually requires. A convenient starting point for this inquiry is rule 139 of the ICRC Study, which closely approximates the narrow interpretation of common Article 1. Rule 139 provides as follows:

Each party to the conflict must respect and ensure respect for international humanitarian law by its armed forces and other persons or groups acting in fact on its instructions, or under its direction or control.

In formulating this rule, the authors of the Study appear to have taken inspiration in the rules of State responsibility. In particular, rule 139 seems to borrow from Draft Article 8 on State Responsibility, which provides as follows:

\section{Conduct directed or controlled by a State}

The conduct of a person or group of persons shall be considered an act of a State under international law if the person or group of persons is in fact acting on the instructions of, or under the direction or control of, that State in carrying out the conduct.

The reasoning behind rule 139 seems to be that since States are responsible for the conduct of persons who act on their instructions or under their direction or control, they must also have a duty to ensure respect for IHL by such persons. While this reasoning is faulty (because one cannot infer the existence of a primary obligation from the secondary rules of State responsibility), the rule itself is correct, subject to three important clarifications.

First, just as States are not responsible for all conduct of persons who act on their instructions or under their direction or control (namely, States are not responsible for conduct that is only peripheral or incidental to their instructions, direction or control), ${ }^{95}$ so too States are not obliged to ensure respect for IHL by such persons at all times, but only when they are in fact directing or controlling the persons in questions.

Second, States are not required to ensure that their instructions are carried out in a lawful manner (i.e. to prevent violations of international law by persons acting on their instructions). The obligation of States in this regard is limited to ensuring that the instructions themselves are compatible with their international obligations. As the ILC's commentary to Draft Article 8 explains, "In general a State, in giving lawful instructions to persons who are not its organs, does not assume the risk that the instructions will be carried out in an internationally unlawful way. ${ }^{\prime 96}$ Nevertheless, it could be argued that the obligation to give lawful 
instructions includes the obligation to ensure that the persons being instructed are aware of their obligations under IHL and that they are willing and able to carry out their instructions in a lawful manner.

Third, it is important to note that rule 139 is incomplete as it makes no reference to the obligation of States to ensure compliance with IHL on the part of their population. As intimated above, it was the understanding of the High Contracting Parties to the Geneva Conventions that the undertaking to "ensure respect" for the Conventions referred specifically to their respective populations. ${ }^{97}$ Interestingly, the ICRC's commentary to Additional Protocol I suggests that the obligation of States in this regard is limited to reminding the civilian population of its obligation under Article 17 of Additional Protocol I to "respect the wounded, sick and shipwrecked, even if they belong to the adverse Party, and [to] commit no act of violence against them." 98 The ICRC's commentary on this provision states that "it is up to the High Contracting Parties to respect and to ensure respect for [the Protocol] in all circumstances, and therefore to instruct the civilian population accordingly." 99 It is clear, however, that the obligation to ensure respect for IHL by the population goes beyond merely issuing instructions. Faced with violations of IHL by its population, the State is obviously obliged to do what it can to suppress the violations. It is just as obvious, however, that this obligation applies only with respect to the population of a territory actually controlled by the State in question. ${ }^{100}$ For instance, it does not apply in territory occupied by another State or controlled by an opposition group. In other words, the obligation to ensure respect for IHL on the part of the population must be understood as an obligation to ensure respect for IHL within the State's own jurisdiction and not on the part of their nationals wherever they may be. It must be understood also as an obligation of conduct rather than as one of result, requiring considerably less of States with regards to the population as a whole than with respect to persons effectively under their control.

\section{CONCLUSION}

Far from being universally accepted by States, the broad interpretation was not contemplated by the High Contracting Parties to the Geneva Conventions and Additional Protocol I and is not confirmed by their subsequent practice. Instead, States are required to ensure respect for IHL only on the part of their own organs and such other persons as may be acting under their effective control. States have also a more general obligation to ensure respect for IHL to the extent possible within their respective jurisdictions. With respect to persons acting on their instructions but outside their effective control, it could be argued that States are required to ensure that such persons are willing and able to execute their instructions in compliance with IHL. It is submitted that reading anything more into common Article 1 is unsupported by IHL and is unlikely to garner the support of States in the near future.

97 Kalshoven, supra note 8. See also Roberts, supra note 15.

98 API, supra note 3.

99 Commentary on the Additional Protocols, supra note 10. Emphasis added.

100 See e.g. Liesbeth Zegveld, The Accountability of Armed Opposition Groups in International Law

(Cambridge: Cambridge University Press, 2002) at 208. 